\title{
Seasons and planting densities interaction on forage production of eight hybrids maize, Ecuador
}

\section{Interacción época/densidad de siembra sobre la producción de ocho híbridos de maíz forrajeros, Ecuador}

\author{
Álvaro Cañadas $L,{ }^{1 *}$ Ph.D, Carlos Molina $H,{ }^{1}$ M.Sc, Diana Rade $L,{ }^{2}$ M.Sc, \\ Francisco Fernández M, ${ }^{3}$ M.Sc.
}

\begin{abstract}
${ }^{1}$ Instituto Nacional de Investigaciones Nacionales, Estación Experimental Tropical Pichilingue, Km 5 vía Quevedo - El Empalme, cantón Mocache, Provincia Los Ríos, Ecuador. ${ }^{2}$ Escuela Superior Politécnica Agropecuaria de Manabí. Docente Investigador del Centro de Investigación de las Carreras de la ESPAM-MFL (CICEM). Campus Politécnico Calceta, Sitio El Limón, Calceta, Ecuador. ${ }^{3}$ Escuela Superior Politécnica Agropecuaria de Manabí del Centro de Investigación de las Carreras de la ESPAMMFL (CICEM). Campus Politécnico Calceta, Sitio El Limón, Calceta, Ecuador. *Correspondencia: alvarogustavo.canadaslopez@alumni.uni-goettingen.de
\end{abstract}

Received: February 2015; Accepted: June 2015.

\begin{abstract}
Objective. To assess the interaction effect of the season and planting densities on the production of eight INIAP corn hybrids. Materials and methods. A research process was conducted in 2013. It was applied a split - split plot design with three replication and Tukey test was used. It was evaluated two planting seasons ( 28 January and 8 April), they were placed in large plots. Two planting densities $(65,500$ y 125,000 plants/ha), that were located in the subplots and eight INIAP corn hybrids arranged in the sub- subplots. The evaluated variables were Fresh Matter, Dry Matter, Plant Height and Crude Protein Results. Fresh Matter and Crude Protein productions were influenced by planting seasons. Plant densities affected the production of Fresh Matter, Dry Matter and Plant Height, as well as the interaction season by corn INIAP hybrids. While INIAP corn hybrids showed statistical differences in the production of Fresh, Dry Matter, Plant Height and Crude Protein. The eight INIAP hybrids productions were: Fresh Matter (58.86 ton/ha \pm 5.19$)$; Dry Matter (21.45 ton/ha \pm 4.71$)$; Plant Height

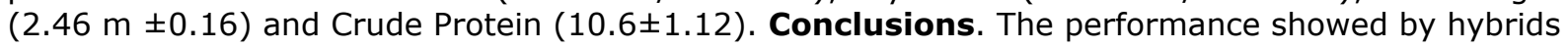
INIAP CML-172, INIAP 6021 and INIAP 551 were very acceptable forage material and could be used for silage purposes.
\end{abstract}

Key words: Biological production, forage, plant source protein, silage (Source: $C A B$ ).

\section{RESUMEN}

Objetivo. Evaluar el efecto de la interacción época y densidad de siembra en ocho híbridos de maíz para producción de forraje sobre la obtención de materia fresca MF, seca MS, altura de planta AP y proteína cruda PC. Materiales y métodos. Se empleó un diseño de parcela dos veces dividida con tres repeticiones. Se evaluó el efecto de dos épocas de siembra ( 28 de enero y el 8 de abril) que se dispusieron en la parcelas grandes, dos densidades de siembra (65.500 y 125.000 plantas/ha) que se ubicaron en las subparcelas y ocho híbridos de maíz INIAP dispuestas en las sub-subparcelas. Las variables evaluadas fueron producción de MF, MS, AP y PC. Resultados. La época de siembra tuvo 
su influencia sobre la producción de MF y contenido de PC. La densidad de cultivo y época de siembra afectó la producción de MF, MS y AP por híbridos de maíz. Mientras que los híbridos INIAP de maíz mostraron diferencias estadísticas $(\mathrm{p}<0.001)$ en la producción de MF, MS, AP y PC. La producción de los ocho híbridos INIAP fue de MF (58.86 Ton/ha \pm 5.19$) ;$ MS (21.45 Ton/ha \pm 4.71$) ;$ AP (2.46 $\mathrm{m} \pm 0.16)$ y $\mathrm{PC}(10.6 \pm 1.12)$. Conclusiones. Los rendimientos mostrados por los híbridos INIAP CML 172, INIAP 6021 e INIAP 551 son materiales aceptables con relación a las variables evaluadas y pueden ser empleados especialmente para ensilaje.

Palabras clave: Ensilaje, forraje, producción biológica, proteína de fuente vegetal (Fuente: CAB).

\section{INTRODUCTION}

According to Cornejo and Wilkie (1) in the latest National Agricultural Census, Ecuador has an approximate bovine population of 4.5 million, dispersed throughout the nation; $51 \%$ in the interAndean region, $37 \%$ along the coast and $12 \%$ in the Amazon for milk and beef production. This cattle population is on a land extension of 3.35 million hectares of cultivated grassland and 1.12 million hectares of natural grassland (1). Of the total amount, 55\% are criollo breed, $43 \%$ are Holstein $\mathrm{F}$, Brahman and Cebuina hybrids and others; a small amount corresponds to pure breeds for meat, milk and double purposes. The total number of production units, about 427,000 are in one way or another used for this purpose (1).

Most of the livestock along the Ecuadorian coast is in areas where lack of rain in the summer results in pasture drying up, thus resulting in a deficit in the supply of cattle feed that results in economic and productive loss, including: absent or diminished heat, weight loss, reduced growth of young animals, birth of weak calves and higher rates of illness and death (2).

Corn silage is widely used for lactating dairy cows that require energy-dense feed to maximize milk production. Decreased water availability is a critical element for agricultural sustainability, particularly in semi-arid regions of the world where there is not a sufficient supply of rainfall. To achieve adequate yields it is necessary to complement this water deficit by irrigation (3). The decline of water resources is exacerbated by an increasing demand for quality fodder necessary to obtain milk. To produce high energy corn silage, an adequate supply of water is necessary at the stage of grain filling. Thus, dependence on the production of dry matter in contrast with its availability is an important factor in maize production (4).

Many components - environmental, cultural and genetic - quantitatively and qualitatively affect the production of fodder maize. Corn planting density can be increased in order to provide maximum production of dry matter (5). Since grain moisture is not of great interest in silage,

\section{INTRODUCCIÓN}

De acuerdo a Cornejo y Wilkie (1), en el último Censo Agropecuario Nacional, Ecuador cuenta con una población aproximada de 4.5 millones de bovinos, distribuidos en todo el territorio nacional, el $51 \%$ en la región interandina, 37\% en el litoral o costa y el $12 \%$ en la Amazonía, para la producción de leche y carne. Esta población ganadera se encuentra asentada en una superficie de 3.35 millones de hectáreas de pastos cultivados y 1.12 millones de hectáreas de pastos naturales (1). Del total de las existencias; el $55 \%$ pertenecen a la raza criolla, $43 \%$ mestizos Holstein F; Brahman; Cebuina y otros; una mínima proporción corresponde a razas puras para la línea carne, leche y doble propósito; siendo el número de unidades de producción, alrededor de 427 mil, que de una u otra manera se dedican a esta actividad (1).

La mayor parte de la ganadería de la costa ecuatoriana se desarrolla en zonas donde los pastos, por la escasez o carencia de lluvia, se secan durante el verano, resultando como consecuencia un déficit en la oferta de alimento para el ganado, que acarrean pérdidas de carácter económico y productivo como son: ausencia o disminución de celo, pérdida de peso, disminución del crecimiento de los animales jóvenes, nacimiento de crías débiles e índices elevados de enfermedades y muertes (2).

El ensilado de maíz es empleado extensamente para vacas lecheras lactantes que requieren alimentos ricos en energía con la finalidad de maximizar la producción lechera. El decrecimiento en la disponibilidad de agua es un elemento crítico, para la sostenibilidad de la agricultura, particularmente en regiones semi-áridas del mundo, la cantidad de agua no es suficientemente abastecida por las precipitaciones, por lo que para alcanzar buenos rendimientos sería necesario complementar este déficit hídrico mediante riego (3). La declinación de los recursos hídricos se agrava aún más por el incremento de la demanda de forrajes de calidad necesarios para la obtención de leche. Para la producción de forraje de maíz de alto valor energético se 
maize hybrids with higher leaf area and plant height may be employed. Planting density for silage has been essential for both grain production and fodder (6). It has been determined that optimal seeding density depends on the properties of the hybrid (7). Yilmaz et al (6) reported that fodder and dry matter production were significantly influenced by patterns of planting and seeding corn hybrids.

There is a lack of precise information about the time and density planting for eight corn hybrids to produce high yields of fodder. Many experiments have been conducted to determine optimum planting density and sowing times for products developed by the National Institute of Agricultural Research (INIAP) for corn production. However, nothing is known about the behavior of these materials developed by INIAP for fodder production in relation to seasons and planting densities. Thus, the present study aims to evaluate how the time of planting and density affects eight corn hybrids in relation to production of fresh matter (MF), dry matter (MS), plant height (AP), and crude protein (PC) to obtain the greatest amounts of fodder maize in the INIAP Pichilingue Tropical Experimental Station, Ecuador.

\section{MATERIALS AND METHODS}

Experimental area. This study took place at the Pichilingue Experimental Tropical Station (EETP) located in the West of the Andes Mountains at $75 \mathrm{~m}$ above sea level. The representative climatic season in the research area is Pichilingue, at $79^{\circ} 21^{\prime} \mathrm{W}$ and $1^{\circ} 06^{\prime} \mathrm{S}$, with an average annual temperature of $25.47^{\circ} \mathrm{C}$, relative humidity at $85.84 \%$, with a heliophany of 898.66 hours light/year, a uni-modal type precipitation with a total of $2.000 \mathrm{~mm} /$ year and its distribution is show in in Figure 1.

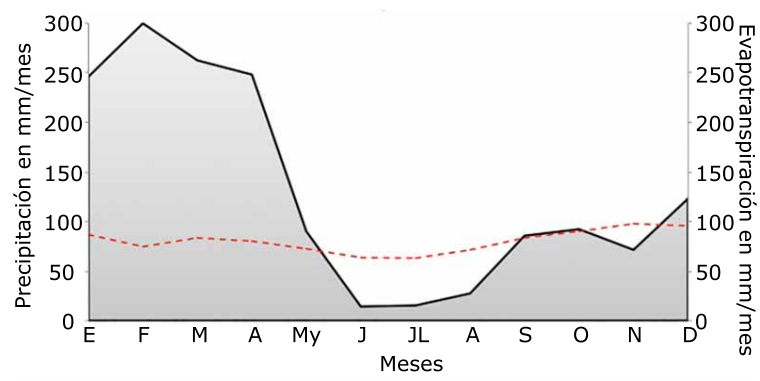

Figure 1. Monthly distribution of precipitation in relation to the potential evapotranspiration model (red line). The fallow area represents the dry months at the Pichilingue weather station.

Cañadas et al (8) developed a model that predicts the value of evapotranspiration for 2013, which is described below and was applied to determine the hydric balance in the study area: requiere suministrar adecuadamente de agua en el momento del llenado de grano. De tal manera que, la dependencia de la producción de materia seca sobre la disponibilidad de la misma es un importante factor en la producción del cultivo del maíz (4).

Muchos componentes entre ambientales, culturales y genéticos afectan cuantitativamente como cualitativamente la producción del forraje del maíz. La densidad de siembra del maíz puede ser incrementada con la finalidad de proveer el máximo de producción de materia seca (5). Desde que la humedad del grano no es de gran interés para el ensilaje, los híbridos de maíz que tienen áreas foliares mayores y altura de planta pueden ser empleados. La recomendación de la densidad de siembra para el ensilaje ha sido esencial tanto para la producción de grano como para el forraje (6). Se ha determinado que el óptimo de la densidad de siembra depende de las propiedades de los híbridos (7). Yilmaz et al (6), reportaron que el forraje y la producción de materia seca fueron significantemente influenciadas por los patrones de siembra, densidad de siembra e híbridos de maíz.

Se carece de información precisa sobre la época y densidad de siembra de ocho híbridos de maíz que permitan obtener altos rendimientos de forrajes. Muchos experimentos han sido conducidos para determinar el óptimo de densidad de siembra y épocas de siembra de los materiales desarrollados por el Instituto Nacional de Investigaciones Agropecuarias (INIAP) para producción de grano de maíz. No obstante, nada se sabe del comportamiento de estos materiales desarrollados por INIAP sometidos a la producción de forraje frente al comportamiento de épocas y densidades de siembra. De tal manera, que la presente investigación tiene por objetivo evaluar cómo afecta la época de siembra, densidad de siembra sobre ocho híbridos de maíz en relación a producción de materia fresca (MF), materia seca (MS), altura de planta (AP) y proteína cruda (PC), como base para obtener el máximo provecho de los maíces forrajeros en el área de influencia de la Estación Experimental Tropical Pichilingue del INIAP, Ecuador.

\section{MATERIALES Y MÉTODOS}

Caracterización del área experimental. La presente investigación se llevó a cabo en la Estación Experimental Tropical Pichilingue (EETP), ubicada en la parte Oeste de la cordillera de Los Andes, a una altura sobre el nivel del mar de 75 m. La estación climatológica representativa del área de investigación es la estación Pichilingue,

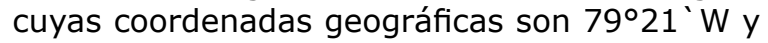


$\mathrm{PET}=20.57 * \mathrm{Es} *(1-\mathrm{HR} / 100)$

Where:

PET = Evapotranspiration ( $\mathrm{mm} /$ month)

$E s=$ Saturated steam pressure ( $m$ bar)

$H R=$ Relative humidity

The values of monthly evapotranspiration (dotted line) are represented opposite average annual rainfall (Figure 1 ). These two parameters determined the hydric balance of the Pichilingue station so that the months that showed a deficit in water availability were June, July, August, October and November (Figure 1, benefited area). The province of Los Ríos is within a Tropical RainForest (9).

Data collection. Soil preparation for the experiment consisted of: fallow land, tracking, leveling, and preparation of furrows. In the last tilling, triple super phosphate was broadcast (0-46-0) and potassium murate (0-0-60). Fifteen days later, nitrogen was incorporated (corresponding to $150 \mathrm{~kg}$ of urea/ha) and at thirty days nitrogen was again applied (corresponding to $150 \mathrm{~kg}$ of urea/ha). This was done at the beginning of the rainy season, on January 28, 2013 and April 8, 2013 at the end of the rainy season (Figure 1). The spacing was $20 \mathrm{~cm}$ between each plant and $80 \mathrm{~cm}$ between rows $(65,500$ plants/ha) and $20 \mathrm{~cm}$ between plants and 40 between rows (125,000 plants/ha), using genetic material developed by INIAP: 1) (6016) L-41-2-6-1-PICHILINGUE-7928- $X$ L- 237-2-1-3-POBLACION-A1XCML-172; 2) (6017) L-37-7-3-4-POZA RICA-8024 X L237-2-1-3-POBLACION-A1 X CML-172; 3) (6020) L-41-2-6-1-PICHILINGUE-7928-X CML-171 X CML172; 4) (6021) L- 41-2-6-1-PICHILINGUE-7928$X$ L-37-7-3-4-2-POZA RICA-8024 X CML-172; 5) $L-41-2-6-1-10 \neq P I C H I L I N G U E-7928-X$ L 237-7-3-4-2-POB-A1 (INIAP H 553); 6) L-237-2-1-3-6POBLACION-A1-X-(CML-172); 7) INIAP-H-551; 8) INIAP $\mathrm{H}-601$.

Statistical analysis. A twice divided plot design was used, two rainy periods were established in large plots and in the subplots two seeding densities were established and in the plots were available sub-subplots eight maize hybrids were established with three replications. Each treatment was established on plots of $100 \mathrm{~m}^{2}$ and a total area of 3,600 $\mathrm{m}^{2}$. Analysis of variance was performed using the SAS program (10), and to test for differences between treatment averages the Tukey test was used at five percent.

Fodder production was determined in tons per hectare, harvesting it in from two central rows from the net plot without sampling the last meter at the ends of each row. A digital scale was used $1^{\circ} 06^{`} \mathrm{~S}$, presenta una temperatura promedio anual de $25.47^{\circ} \mathrm{C}$, humedad relativa de $85.84 \%$, acogiendo a una heliofanía de 898.66 horas luz/año, su precipitación es de tipo uni-modal, recibiendo un total de $2.000 \mathrm{~mm} / \mathrm{año}$ y su distribución es representada en la figura 1 .

Cañadas et al (8), desarrolló un modelo que permitió predecir los valores de evapotranspiración para el año 2013, el cual se describe a continuación y fue aplicado para determinar el balance hídrico en el área de investigación:

$\mathrm{PET}=20.57 * \mathrm{Es}^{*}(1-\mathrm{HR} / 100)$

Donde:

$P E T=$ Evapotranspiración $(\mathrm{mm} / \mathrm{mes})$

$E s=$ Presión de saturación de vapor (m bar)

$H R=$ Humedad relativa

Los valores de evapotranspiración mensual (Línea punteada) son representados en confrontación con la precipitación promedio anual (Figura 1). Estos dos parámetros determinaron el balance hídrico en la estación Pichilingue, de tal manera que, los meses que presentaron un déficit de disponibilidad de agua fueron junio, julio, agosto, octubre y noviembre (Figura 1, zona achurada). La provincia de Los Ríos pertenece a la formación ecológica de Bosque Húmedo Tropical (9).

Obtención de datos. La preparación del suelo del experimento consistió en: un barbecho, rastreo cruzado, nivelación, trazo de surcos. En el último pase de rastra se aplicó al boleo superfosfato triple (0-46-0) y muriato de potasio (0-0-60). Luego de 15 días de la siembra se incorporó nitrógeno (equivalente a 200 kg de urea/ha), a los 30 días se volvió a aplicar nitrógeno (equivalente a $150 \mathrm{~kg}$ de urea/ha). La siembra se realizó al inicio de la época de lluvia el 28 de enero del 2013 y el 8 de abril del 2013 en el declive de la época de precipitación (Figura 1). El espaciamiento de siembra, se dispuso de $20 \mathrm{~cm}$ entre planta y $80 \mathrm{~cm}$ entre surcos $(65,500$ plantas/ha) y $20 \mathrm{~cm}$ entre plantas y 40 entre surcos (125,000 pantas/ha), empleando el material genético desarrollado por INIAP: 1) (6016) L-41-2-6-1-PICHILINGUE-7928- $X$ L- 237-2-1-3-POBLACION-A1XCML-172; 2) (6017) L-37-7-3-4-POZA RICA-8024 X L237-2-1-3-POBLACION-A1 X CML-172; 3) (6020) L-41-2-6-1-PICHILINGUE-7928-X CML-171 X CML172; 4) (6021) L- 41-2-6-1-PICHILINGUE-7928$X$ L-37-7-3-4-2-POZA RICA-8024 X CML-172; 5) $\mathrm{L}-41-2-6-1-10 \neq \mathrm{PICHILINGUE}-7928-\mathrm{X}$ L 237-7-3-4-2-POB-A1 (INIAP H 553); 6) L-237-2-1-3-6POBLACION-A1-X-(CML-172); 7) INIAP-H-551; 8) INIAP $\mathrm{H}-601$. 
with a 40 kilograms capacity. A $1 \mathrm{~kg}$ sample of fresh fodder from each plot was taken, placed in paper bags, and sent to the Quality and Nutrition Laboratory of the Santa Catalina Experimental Station to be oven dried at $70^{\circ} \mathrm{C}$ for $48 \mathrm{~h}$. The samples were weighed and put in the oven for an additional $12 \mathrm{~h}$ to obtain a constant weight and were then weighed to establish the production of dry matter. At the end of the study, ten plants in the net plot were measured at random to determine plant height. The crude protein content was obtained according to the method proposed by AOAC (11).

\section{RESULTS}

Production of fresh material. In table 1 , the analysis of variance is presented for fresh material.

Table 1. Significance of half squares for Fresh Material, Dry Material, Plant Height and Crude Protein for eight INIAP hybrids in two seasons and two planting densities at the Pichilingue Tropical Experimental Station.

\begin{tabular}{|c|c|c|c|c|c|}
\hline $\begin{array}{l}\text { Source of } \\
\text { variation }\end{array}$ & $\begin{array}{l}\text { Degrees } \\
\text { of liberty }\end{array}$ & MF & MS & AP & PC \\
\hline Repetitions & 2 & 5.45 & 2.32 & 0.26 & 0.07 \\
\hline Season (E) & 1 & $956.34 * * *$ & $46.76^{\mathrm{ns}}$ & $0.52^{\text {ns }}$ & $8.76 * *$ \\
\hline Type A Error & 2 & 1.53 & 3.14 & 0.007 & 0.32 \\
\hline Density (D) & 1 & $799.26 * * *$ & $0.09 * *$ & $0.23 *$ & $0.84^{\text {ns }}$ \\
\hline$E \times D$ & 1 & $7.59 \mathrm{~ns}$ & $86.26 \mathrm{~ns}$ & $0.03^{\text {ns }}$ & $0.01^{\text {ns }}$ \\
\hline Type B Error & 4 & 2.70 & 28.33 & 0.02 & 0.437 \\
\hline $\begin{array}{l}\text { INIAP hybrids } \\
\text { (H) }\end{array}$ & 7 & $64.07 * * *$ & $127.39 * * *$ & $0.04 * *$ & $12.84 * * *$ \\
\hline $\mathrm{E} \times \mathrm{H}$ & 7 & $40.16^{\mathrm{ns}}$ & $2.99^{\mathrm{ns}}$ & $0.001^{\mathrm{ns}}$ & $0.07^{\mathrm{ns}}$ \\
\hline $\mathrm{D} \times \mathrm{H}$ & 7 & $30.82^{\mathrm{ns}}$ & $51.47 * * *$ & $0.03^{\mathrm{ns}}$ & $0.82^{\mathrm{ns}}$ \\
\hline$E \times D \times H$ & 7 & $189.75^{\mathrm{ns}}$ & $5.74^{\mathrm{ns}}$ & $0.0003^{n s}$ & $0.12^{\mathrm{ns}}$ \\
\hline Type C Error & 56 & 263.24 & 6.36 & 0.01 & 0.23 \\
\hline Total & 96 & & & & \\
\hline
\end{tabular}

A high statistical significance $(p<0.001)$ for density and planting seasons and INIAP maize hybrids were found. The variation coefficients for large plots $2.10 \%$, sub plots $2.81 \%$ and sub-subplots $2.13 \%$ support the results obtained for this parameter. Using the Tukey measurement test at five percent, the first range of statistical significance was determined (Figure 2A) during the planting season on January 282013 and planting density at 125,000 plants/ha (Figure 2B).

A high statistical difference $(p<0.001)$ was detected for INIAP hybrids (Table 2 ) where the means for MF was presented, and they were placed in three significant mean ranges. The INIAP 551, INIAP H 601, INIAP H 553 hybrids were in the first range and INIAP CML-172 in the second.
Análisis estadístico. Se empleó un diseño de parcela dos veces dividida, dónde en las parcelas grandes se ubicaron dos épocas de lluvia, en las subparcelas se establecieron dos densidades de siembra y en las subsub-parcelas se dispuso de ocho híbridos de maíz con tres repeticiones. Cada tratamiento estuvo instaurado en parcelas de $100 \mathrm{~m}^{2}$ y una superficie total de $3.600 \mathrm{~m}^{2}$. El análisis de varianza se realizó empleando el programa SAS (10), para probar las diferencias entre medias de tratamientos se empleó la prueba de Tukey al cinco por ciento.

Se determinó la producción de forraje en toneladas por hectárea, cosechando el forraje de dos surcos centrales de la parcela neta, sin tomar muestras del último metro al extremo de cada surco y se empleó una báscula digital con capacidad de 40 kilogramos. Del forraje fresco de cada parcela se tomó una prueba de $1 \mathrm{~kg}$, luego se colocó en fundas de papel y se enviaron al Laboratorio de Calidad y Nutrición de la Estación Experimental Santa Catalina, para ser deshidratadas en estufa a temperatura de $70^{\circ} \mathrm{C}$ por $48 \mathrm{~h}$. Las muestras fueron pesadas e introducidas a la estufa por $12 \mathrm{~h}$ adicionales hasta obtener un peso constante y se pesaron para establecer la producción de materia seca. Dentro de la parcela neta al final del experimento se midieron diez plantas al azar para fijar la altura de planta. El contenido de proteína cruda se obtuvo de acuerdo a la metodología propuesta por AOAC (11).

\section{RESULTADOS}

Producción de materia fresca. En la tabla 1 , se presenta el análisis de varianza para materia fresca. Se detectó una alta significancia estadística $(p<0.001)$ para densidad y épocas de siembra e híbridos INIAP de maíz. Los coeficientes de variación para parcelas grandes de $2.10 \%$, subparcelas de $2.81 \%$ y subsubparcelas $2.13 \%$ avalan los resultados obtenidos para este parámetro. Realizada la prueba de medias de Tukey al cinco por ciento, se ubicaron en el primer rango de significancia estadística (Figura 2A) a la época de siembra 28 de enero del 2013 y la densidad de siembra de 125.000 plantas/ ha (Figura 2B).

Una alta diferencia estadística $(p<0.001)$ se detectó para los híbridos INIAP (Tabla 2), donde se presenta la comparación de medias para MF, se discriminaron en tres rangos significativos de medias. Estando los híbridos INIAP 551, INIAP H 601, INIAP H 553 en primer rango e INIAP CML-172 en el segundo. 


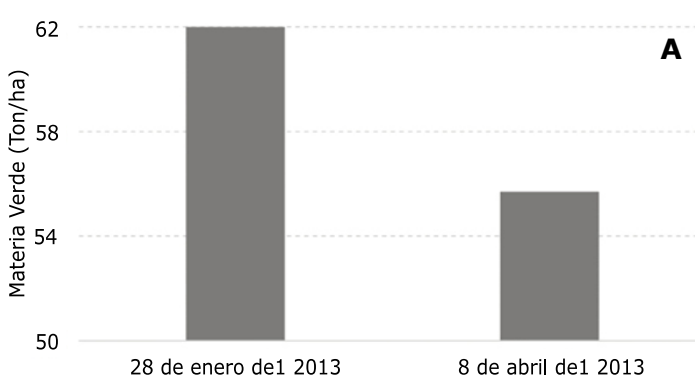

Época de Siembra

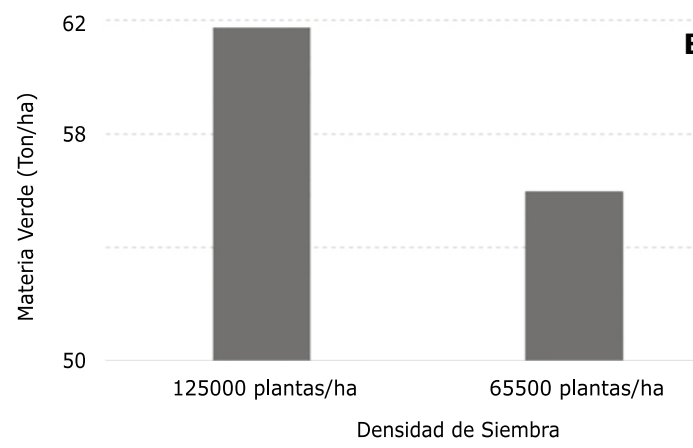

Figure 2. A. MF production (Ton/ha) for two planting seasons, EETP. B. MF Production (Ton/ha) for two planting densities, EETP.

Production of dry material. A high statistical significance $(p<0.01)$ was detected for planting densities where the population of 125.000 plants/ ha was placed in the first range with 21.02 Ton/ha and in the second one the density was found (65.500 plants/ha) with a production of 20.95 Ton/ha according to the Tukey test (Table $1)$. A high statistical discrepancy $(p<0.001)$ showed INIAP maize hybrids (Table 2 ), where the averages are observed, the Tukey test discriminated in three average ranges. In the first range was the INIAP 6020 hybrid, in the second INIAP 553, INIAP CML-172 and in the third INAIP 6017 , INIAP 6016, INIAP 551, INIAP H 601. The variation coefficients for large plots was $2.10 \%$, subplots $2.81 \%$ and sub-sub-plots $2.13 \%$ back up the results.

Table 2. Statistical significance of half squares for Fresh Material, Dry Material, Plant Height and Crude Protein for eight INIAP hybrids in two seasons and two planting densities at the Pichilingue Tropical Experimental Station.

\begin{tabular}{lcccc}
\hline Genotypes & MV & MS & AP & PC \\
\hline INIAP 551 & $61.58^{\mathrm{a}}$ & $18.92^{\mathrm{c}}$ & $2.40^{\mathrm{b}}$ & $10.50^{\mathrm{b}}$ \\
INIAP H 601 & $60.92^{\mathrm{a}}$ & $18.75^{\mathrm{c}}$ & $2.41^{\mathrm{b}}$ & $9.25^{\mathrm{d}}$ \\
INIAP H 553 & $60.42^{\mathrm{a}}$ & $23.17^{\mathrm{b}}$ & $2.44^{\mathrm{b}}$ & $10.33^{\mathrm{b}}$ \\
INIAP CML-172 & $60.17^{\mathrm{a}}$ & $20.42^{\mathrm{b}}$ & $2.44^{\mathrm{b}}$ & $11.66^{\mathrm{a}}$ \\
INIAP 6021 & $59.16^{\mathrm{b}}$ & $19.33^{\mathrm{c}}$ & $2.45^{\mathrm{b}}$ & $11.42^{\mathrm{a}}$ \\
INIAP 6020 & $56.58^{\mathrm{c}}$ & $28.25^{\mathrm{a}}$ & $2.39^{\mathrm{b}}$ & $9.51^{\mathrm{c}}$ \\
INIAP 6017 & $56.56^{\mathrm{c}}$ & $19.92^{\mathrm{c}}$ & $2.60^{\mathrm{a}}$ & $8.67^{\mathrm{d}}$ \\
INIAP 6016 & $55.50^{\mathrm{c}}$ & $19.17^{\mathrm{c}}$ & $2.47^{\mathrm{a}}$ & $10.08^{\mathrm{b}}$ \\
Average & 58.86 & 21.45 & 2.46 & 10.62 \\
Treatments with the same letter indicate statistical equality.
\end{tabular}

Producción de materia seca. Se detectó una alta significancia estadística $(p<0.01)$ para densidades de siembra, donde la población de 125.000 plantas/ha se ubicó en primer rango con 21.02 Ton/ha y en el segundo se encontró la densidad (65.500 plantas/ha) con una producción de $20.95 \mathrm{Ton} / \mathrm{ha}$ de acuerdo con la prueba de Tukey (Tabla 1). Una alta discrepancia estadística $(p<0.001)$ mostraron los híbridos de maíz INIAP (Tabla 2), donde se observan los promedios, la prueba de Tukey discriminó en tres rangos de promedio. En el primer rango estuvo el híbrido INIAP 6020, en el segundo INIAP 553, INIAP CML-172 y el tercero INAIP 6017, INIAP 6016, INIAP 551, INIAP H 601. Los coeficientes de variación para parcelas grandes de $2.10 \%$, subparcelas de $2.81 \%$ y subsubparcelas $2.13 \%$ avalan los resultados obtenidos.

En la figura 3, se presenta el promedio de la producción de materia seca para la interacción densidad por híbridos INIAP; demostrando la reacción de los diferentes híbridos a la densidad de siembra. La interacción que mayor producción de materia seca destaca fue la densidad 125.000 plantas/ha por el híbrido INIAP 6020 (32.08 Ton/ha).

Altura de planta. Esta variable presentó significancia $(p<0.05)$ para densidades de siembra en concordancia con la altura de planta. De igual manera, se estableció una alta variación estadística $(p<0.01)$ para híbridos INIAP. Realizada la comparación de medias se determinaron dos rangos de significancia (Tabla 2). En el primer rango se ubicaron INIAP 6017, INIAP 6016 y en el siguiente INIAP 551; INIAP H 601; INIAP H 553; INIAP CML-172; INIAP 6021 e INIAP 6020 (Tabla 2). Los coeficientes de variación para parcelas grandes de $1.50 \%$, subparcelas de $7.14 \%$ y subsubparcelas $10.13 \%$ son apropiados para investigaciones de campo.

Proteína cruda. Se observó significancia estadística $(p<0.05)$, para el contenido de PC, la cual está influenciada por la época de siembra. Realizada la prueba de Tukey se dividió en dos rangos de clasificación de medias, en el primero se encontró la época de siembra 28 de enero del 2013 con un promedio de $10.45 \%$ y el segundo 8 de abril con un promedio de $9.87 \%$. Para híbridos INIAP de maíz se encontró una mayor diferencia estadística en el porcentaje de PC $(p<0.0001)$. Se detectaron cuatro rangos de medias de acuerdo a Tukey, en el primero se encontró a los híbridos INIAP CML-172 e INIAP 6021, en el segundo INIAP 551, INIAP H 553 e INIAP 6016, en el tercero INIAP 6020 y el cuarto INIAP H 601 e INIAP 6017 (Tabla 2). Los coeficientes de variación para parcelas 


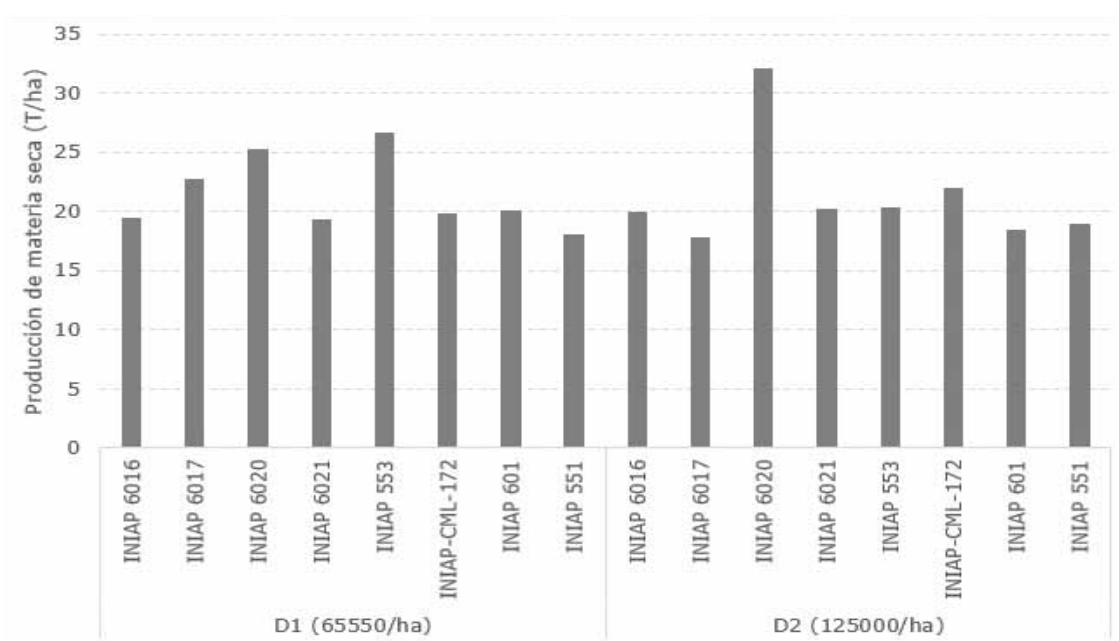

Figure 3. Density interaction for planting INIAP hybrids in relation to production of dry material, Pichilingue Station 2013.

In figure 3, the average dry matter production for density interaction in INIAP hybrids is presented, showing the reaction of different hybrids to planting density. The interaction that increased production of dry matter density was 125.000 plants/ha for the INIAP 6020 hybrid (32.08 t/ha).

Plant height. This variable presented significance $(p<0.05)$ for planting densities according to plant height. Similarly, a high statistical variation $(p<0.01)$ was established for INIAP hybrids. By comparing measurements, two ranges of significance were determined (Table 2). In the first range INIAP 6017, INIAP 6016 were placed, and in the following one INIAP 551; INIAP H 601; INIAP H 553; INIAP CML-172; INIAP 6021 and INIAP 6020 (Table 2). The variation coefficients for large lots was $1.50 \%$, subplots $7.14 \%$ and sub-subplots $10.13 \%$ are appropriate for field studies.

Crude protein. A statistical significance was found $(p<0.05)$, for PC content, which is influenced by the planting season. After doing the Tukey test, it was divided in two mean ranges of classification, in the first the January 282013 planting season was found with an average of $10.45 \%$ and the second April 8 with an average of $9.87 \%$. For INIAP maize hybrids a major statistical difference was found in the percentage of PC $(p<0.0001)$. Four mean ranges were detected according to Tukey, in the first one INIAP CML-172 and INIAP 6021 hybrids was found, in the second one INIAP 551, INIAP H 553 and INIAP 6016, in the third INIAP 6020, and in the fourth INIAP H 601 and INIAP 6017 (Table 2 ). The variation coefficients for large plots at $5.58 \%$, subplots at $6.42 \%$ and sub-subplots at $4.70 \%$ support the findings in this study. grandes de $5.58 \%$, subparcelas de $6.42 \%$ y subsubparcelas $4.70 \%$ avalan los resultados obtenidos en esta investigación.

\section{DISCUSIÓN}

Influencia sobre materia verde. Una relación directa entre disponibilidad de agua a través de la época de siembran y la producción de materia fresca de maíz fue establecida. Es decir que, a mayor acervo de agua mayor será la producción de materia fresca de maíz. Estos resultados son consistentes con los encontrados por Ramírez et al (12) y Montemayor et al (13), quienes reportaron un incremento de 2.5 veces la producción de materia fresca del maíz pasando de riego gravitacional testigo a un riego más denso de riego por goteo.

La producción de materia fresca fue afectada significativa y directamente proporcional con relación a la densidad de siembra; incrementando la densidad de siembra (por ejemplo de 40.000 a 100.000 plantas/ha) en maíz es un método empleado para ampliar la producción de biomasa, debido a los acrecentamientos de los procesos internos, índices de área foliar, intercepción de luz y rango de crecimiento (14). Para la producción total de material fresca, Yilmaz et al (6), concluyeron que, la producción de forraje difiere estadísticamente a lo largo de las densidades de siembra y se incrementa consistentemente a partir de 114.000 plantas/ha, para disminuir a partir de 143.000 planta/ha.

Los híbridos de mayor producción promedio de materia fresca fueron INIAP 551 (61.58 Ton/ ha), INIAP H 601 (60.92 Ton/ha), INIAP H 553 (60.42 Ton/ha) e INIAP CML-172 (60.17 Ton/ ha). Estos datos pueden ser comparados con 


\section{DISCUSSION}

Influence on fresh matter. A direct relationship between water supply at the time of planting and the production of fresh maize was established. That is, a larger supply of water increased the production of fresh maize. These results are consistent with those reported by Ramirez et al (12) and Montemayor et al (13) who reported that the production of fresh maize increased 2.5 times when they went from using gravitational irrigation to a more intense drip irrigation.

Fresh matter production was significantly affected proportional to planting. Increasing planting density (from 40.000 to 100.000 plants / ha) is a method employed to increase production of biomass due to increased internal processes, leaf area indexes, light interception, and growth range (14). Regarding total production of fresh material, Yilmaz et al (6), concluded that fodder production differs statistically with planting densities and consistently increases from 114,000 plants/ha, and decreases from 143,000 plant/ha.

The hybrids with greater average production of fresh material were INIAP 551 (61.58 Tons/ ha), INIAP H 601 (60.92 Tons/ha), INIAP H 553 (60.42 Tons/ha) and INIAP CML-172 (60.17 Tons/ha). These data can be compared with those obtained in Colombia in the Middle Sinú Valley by Cabrales et al (15), who evaluated 25 fodder maize genotypes and the best ones were Vera-225 (61.13 Tons/ha), SNPL-111 (60.62 Tons/ ha) and ICA-V-156 (60.42 Tons/ha). According to Núñez et al (16) in a study conducted in Mexico with hybrid maize, fodder producers established a density of 80 thousand plants/ha with irrigation and three phases of maturity, with an average of 57.90 Tons/ha of green fodder, and from there we can see that the productivity of hybrid INIAP maize is acceptable.

Influence on dry matter. The planting density at 125,000 plants / a used in this study expresses a higher yield production for this parameter. Hence, the use of high densities of corn is a way of optimizing the soil use (17). Turgut et al (18), Yilmaz et al (6), and Budakli-Carpici (19) reported that different densities to maximize dry matter production range from 70,000 to 165,000 plants / ha. This trend was observed in this study.

In this investigation, INIAP 6020 hybrid ( 28.25 Tons/ha), followed by INIAP 553 (23.17 Tons/ha) and INIAP CML-172 (20.42 Tons/ha) were the highest producing materials in dry matter. These data can be confronted with those of Cabrales et al (15) who evaluated 25 fodder maize genotypes los obtenidos en Colombia en el valle de Sinú Medio por Cabrales et al (15), donde se realizó la evaluación de 25 genotipos de maíz forrajero y los mejores genotipos fueron Vera-225 (61.13 Ton/ha), SNPL-111 (60.62 Ton/ha) e ICA-V-156 (60.42 Ton/ha). De acuerdo con Núñez et al (16) en su estudio conducido en México con híbridos de maíz productores de forrajes establecidos a una densidad de 80 mil plantas/ha, bajo riego y tres estados de madurez obtuvieron un promedio de 57.90 Ton/ha de forraje verde, de ahí que los rendimientos de los híbridos INIAP de maíz son aceptables.

Influencia sobre materia seca. La densidad de siembra de 125.000 plantas/ha empleada en esta investigación expreso su mayor rendimiento para este parámetro de producción. De ahí que, el empleo de altas densidades de siembra del maíz es una forma de optimización del uso del terreno (17). Turgut et al (18), Yilmaz et al (6), BudakliÇarpici (19) reportaron que, diferentes densidades de siembra para maximizar la producción de materia seca van desde 70.000 a 165.000 plantas/ ha. Esta tendencia fue observada en la presente investigación.

El híbrido INIAP 6020 (28.25 Ton/ha), seguidos por INIAP 553 (23.17 Ton/ha) e INIAP CML-172 (20.42 Ton/ha) fueron los materiales de alta producción de materia seca observados en esta investigación. Estos datos pueden ser confrontados con los de Cabrales et al (15) quienes, realizaron evaluaciones de 25 genotipos de maíz forrajero en el centro de Investigación de Turipaná de Corpoica, departamento de Córdoba, donde el genotipo HIT 34 mostró un total de 22.00 Ton/ha, Vera 225 registró 20.11 Ton/ha y SNLP 111 produjo 19.20 Ton/ha. Los contenidos más bajos de humedad estarían asociados a plantas más maduras.

La interacción que dejó la máxima producción de materia seca, fue la densidad de siembra de 125.000 plantas/ha por el híbrido INIAP 6020 (32.08 Ton/ha). Es decir que, existió una relación directa proporcional entre densidad de siembra y producción de materia seca. Estos resultados son análogos con los encontrados por Budakli-Çarpici et al (19). En este estudio para la época de siembra 8 de abril, las plantas se encontraron con un déficit hídrico para los meses junio y julio (Figura $1)$, lo cual no crearon las mejores condiciones para soportar una mayor densidad de siembra investigada (Figura 3).

Influencia sobre la altura de planta. Se encontró un efecto significativo directamente proporcional entre altura de planta y densidad de siembra. Esta tendencia fue corroborada por Gözübenli (20) quién registró que, la altura de la 
in the Turipaná Investigation Center in Corpoica, Córdoba, where the HIT 34 genotype had a total of 22.00 Tons/ha, Vera 225 recorded 20.11 Tons/ ha and SNLP 111 produced 19.20 Tons/ha. Lower humidity content is associated with more mature plants.

The interaction that showed the greatest production of dry matter was the planting density of 125,000 plants/ha by the INIAP 6020 hybrid (32.08 t/ ha). That is, there was a direct proportional relationship between planting density and dry matter production. These results are similar to those found by Budakli-Carpici et al (19). In that study in the April 8 planting season, the plants had a water deficit in June and July (Figure 1), which did not create the best conditions to support a higher planting density (Figure 3 ).

Influence on plant height. A directly proportionally significant effect between plant height and plant density was found. This trend was confirmed by Gözübenli (20) who showed that plant height increases as a result of plant density and the larger maize plants were measured and showed $2.08 \mathrm{~m}$ at a planting density of 120.000 plants/ha and the lowest was $1.99 \mathrm{~m}$ at a density of 80.000 plants/ ha. Increased maize planting density results in a narrower and longer stem. Studies have revealed that thin stem diameters and large plants were observed at high plant densities (17).

In this investigation the hybrids that reached greater height were INIAP $6017(2.60 \mathrm{~m})$ and INIAP $6016(2.47 \mathrm{~m})$, while the rest of the materials were homogenous: INIAP 6021 (2.45 m); INIAP 553 (2.44 m); INIAP CML-172 (2.44 m); INIAP H 601 $(2.41 \mathrm{~m})$; INIAP 551 (2.40 m) and INIAP 6020 $(2.39 \mathrm{~m})$. Acosta (21) highlighted that an average tropical creole maize plant reaches a height of 2.20 to $3.20 \mathrm{~m}$. Data obtained in this study could be compared to a study done by Sánchez et al (22) who studied the response to the selection of tropical varieties of maize in Mexico and reported an average plant height of 2.13 to $2.22 \mathrm{~m}$. On the other hand, Ramírez et al (12) reported in their evaluation on the behavior of fodder maize under different irrigations in Torreón-San Pedro, Coahuila, Mexico, where gravitational irrigation recorded a height of $2.15 \mathrm{~m}$ and a greater density by drip irrigation was reached, $2.97 \mathrm{~m}$.

Influence on Crude Protein content (PC). Statistical significances for planting seasons $(p<0.05)$ were found; the Tukey test $(5 \%)$ was performed, and the January 28, 2013 planting season came in first for PC content to (10.48\%), followed by the April 82013 planting season $(9.87 \%)$. These results are consistent with those obtained by Marsalis et al (4) and Gallegos et al planta se incrementa como consecuencia de la densidad de siembra y las plantas de maíz más grandes fueron medidas, mostrando $2.08 \mathrm{~m}$ bajo una densidad de siembra de 120.000 plantas/ ha y las más bajas fueron de $1.99 \mathrm{~m}$ a una densidad de 80.000 plantas/ha. El incremento de la densidad de siembra del maíz causa que el tallo se vuelva angosto y a menudo alto. Investigaciones revelaron que, los diámetros delgados de los tallos y plantas grandes fueron observados a altas densidades de plantas (17).

En la presente investigación, los híbridos que alcanzaron la mayor altura fueron INIAP 6017 (2.60 m) e INIAP 6016 (2.47 m), mientras que el resto de materiales fueron homogéneos en la expresión de este carácter: INIAP 6021 (2.45 $\mathrm{m})$; INIAP 553 (2.44 m); INIAP CML-172 (2.44 $\mathrm{m})$; INIAP H 601 (2.41 m); INIAP 551 (2.40 m) e INIAP 6020 (2.39 m). Acosta (21) señaló que un maíz criollo tropical promedio alcanza entre 2.20 a $3.20 \mathrm{~m}$ de altura. Los datos obtenidos en esta investigación podrían ser comparados con el estudio conducido por Sánchez et al (22), al estudiar la respuesta a la selección de variedades tropicales de maíz en México, reportaron una altura de planta promedio de 2.13 a 2.22 m. Por otro lado, Ramírez et al (12), reportaron en su evaluación del comportamiento agronómico de maíces forrajeros bajo diferentes tratamientos de riego en Torreón-San Pedro, Coahuila, México, donde el tratamiento de riego gravitacional registró una altura de $2.15 \mathrm{~m}$ y a una mayor densidad de riego por goteo alcanzó $2.97 \mathrm{~m}$.

Influencia sobre el contenido de Proteína Cruda (PC). Se encontraron significancias estadísticas para épocas de siembra $(p<0.05)$, realizada la prueba de Tukey ( $5 \%$ ) se ubicó en el primer rango de contenido de PC a la época de siembra 28 de enero del 2013 (10.48\%), seguido por la época de siembra de 8 de abril del 2013 (9.87\%). Estos resultados son consistentes con los obtenidos por Marsalis et al (4) y Gallegos et al (23), quienes sostienen que, el contenido de PC de genotipos de maíz se ve afectada por la aplicación de bajos volúmenes de agua de riego.

Cusicanqui y Lauer (24) encontraron un decrecimiento del contenido de PC con el aumento de la densidad de plantación de 44.500 a 104.500 plantas/ha. Estos resultados son respaldados por aquellos estudios conducidos por Cox y Cherney (25) quienes reportaron una reducción de $\mathrm{PC}$ a altas densidades de siembra de maíz (116.000 plantas/ha vs. 80.000 plantas/ ha). Esta tendencia no pudo ser observada en la presente investigación ( $p>0.05)$. 
(23), who argue that the CP content of maize genotypes is affected by low amounts of irrigation water.

Cusicanqui and Lauer (24) found a decrease in the $\mathrm{PC}$ content with an increase in planting density of 44.500 to 104.500 plants/ha. These results are supported by studies conducted by Cox and Cherney (25), who reported a reduction of PC in high planting densities of maize (116,000 plants/ ha vs. 80,000 plants/ha). This tendency was not observed in this study $(p>0.05)$.

Statistical differences between the INIAP material investigated $(p<0.001)$ in the PC content. The general average for INIAP hybrids was $10.62 \%$ $( \pm 1.12)$. Upon performing the Tukey test at $5 \%$, four ranges were established; in the first range INIAP H 553 (11.67\%) and INIAP 6021 (11.42\%). INIAP H 601 (10.50\%) and INIAP $6016(10.08 \%)$ Were in the second range and in the third was INIAP 6020 (9.50\%). In the Municipality of Gómez Palacios, Durango, México, the PC content shown by the fodder maize genotypes San Lorenzo 9.04\%, AS-905 $9.01 \%$ and RS-9022 8.57\% (23) were below the PC content for INIAP hybrids. According to the standards of Peña et al (26), ranges of PC percentages from 8-12 are considered low quality levels.

In conclusion, the maize crop in the Pichilingue Tropical Experimental Extension of the INIAP>S area of influence is seasonally dependent exclusively on rainfall. Results obtained in this study indicate that the time of maximum rainfall (planting date January 28 ) had $11.38 \%$ greater production of green matter than maize planted at the time of reduced rainfall (April 8 planting date). A reduced seeding density of 125.000 to 65.500 plants/ha reduced the production of green matter by $10.30 \%$. Regarding maize hybrid density interaction, the INIAP 6020 hybrid and 125.000 seeding density was $20.11 \%$ greater than the INIAP 551 interaction density by planting 65.500 plants/ha in relation to production of dry material.

The behavior of eight hybrids evaluated in these four variables were diverse. Thus, INIAP CML 172 hybrids with a MF production of 60.17 Tons/ha; MS 20.42 Tons/ha; AP $2.44 \mathrm{~m}$ and PC $11.66 \%$. The INIAP 6021 hybrid with a MF production of 59.16 Tons/ha; MS 19.33 Tons/ha; AP $2.45 \mathrm{~m}$ and PC $10.42 \%$. INIAP 551 hybrid with a MF production of 61.58 Tons/ha; MS 18.92 Tons/ ha; AP $2.40 \mathrm{~m}$ and PC $11.66 \%$. The performance of these three INIAP maize hybrids shows they are very acceptable in relation to the variables evaluated and can be spatially used for silage.
Existió diferencia estadística entre el material investigado de INIAP $(p<0.001)$ en el contenido de PC. El promedio general de los híbridos INIAP fue de $10.62 \%$ ( \pm 1.12$)$. Realizada la prueba de Tukey al $5 \%$, se establecieron cuatro rangos encontrándose en el primer rango INIAP $\mathrm{H}$ $553(11.67 \%)$ e INIAP 6021 (11.42\%). En el segundo rango se ubicó INIAP H 601 (10.50\%) e INIAP $6016(10.08 \%)$ y en el tercero INIAP 6020 (9.50\%). En el Municipio de Gómez Palacios, Durango, México, los contenidos de PC mostrados por los genotipos de maíz forrajeros San Lorenzo 9.04\%, AS-905 9.01\% y RS-9022 $8.57 \%$ (23), estuvieron por debajo del contenido de PC de los híbridos INIAP. Los porcentajes de PC de acuerdo a los estándares de Peña et al (26) rangos de 8 a 12 son considerados como niveles de baja calidad.

En conclusión, el cultivo de maíz en el área de influencia de la Extensión Experimental Tropical Pichilingue del INIAP es estacional dependiente exclusivamente de la precipitación pluvial. Los resultados obtenidos en esta investigación indican que, la época de máxima precipitación (fecha de siembra 28 de enero) fue $11.38 \%$ mayor en producción de materia verde que la siembra de maíz en la época de disminución de las lluvias (fecha de siembra 8 de abril). Mientras que, al bajar la densidad de siembra de 125.000 a 65.500 plantas/ha significa una reducción de un $10.30 \%$ en la producción de materia verde. Con relación a la interacción densidad por híbrido de maíz, el híbrido INIAP 6020 y densidad de siembra 125.000 fue 20.11 $\%$ mayor que, la interacción densidad INIAP 551 por densidad de siembra 65.500 plantas/ha en relación a la producción de material seca.

El comportamiento de los ocho híbridos evaluados en las cuatro variables evaluadas fue diversa. Así, los híbridos INIAP CML 172 con una producción MF de 60.17 Ton/ha; MS 20.42 Ton/ha; AP 2.44 $\mathrm{m}$ y PC $11.66 \%$. El híbrido INIAP 6021 con una producción MF de 59.16 Ton/ha; MS 19.33 Ton/ha; AP $2.45 \mathrm{~m}$ y PC $10.42 \%$. Así como el híbrido INIAP 551 con una producción MF de 61.58 Ton/ha; MS 18.92 Ton/ha; AP $2.40 \mathrm{~m}$ y PC $11.66 \%$. Los rendimientos mostrados por estos tres híbridos INIAP de maíz son materiales muy aceptables en relación a las variables evaluadas y pueden ser empleados espacialmente para ser ensilados.

Se sugiere realizar la evaluación de épocas y densidad de siembra sobre las características nutritivas de estos ocho híbridos de INIAP en relación al contenido de Fibra Detergente Neutra, Fibra Detergente Ácida, Digestibilidad in vitro y Extracto etéreo. Adicionalmente se 
It is recommended that an evaluation of planting times and nutritional characteristics of these eight hybrids INIAP be done regarding the content of neutral detergent fiber, acidic detergent fiber, in vitro digestibility and ethereal extract. Additionally, an economic analysis between maize productions as opposed to fodder production in order to determine its economic viability. debe realizar un análisis económico entre la producción de maíz para la producción de grano en contraposición con la producción de maíz forrajero con la finalidad de ver la viabilidad económica de esta práctica de producción.

\section{REFERENCES}

1. Cornejo C, Wilkie A. Greenhouse gas emissions and biogas potential from livestock in Ecuador. Energy Sustain Dev 2010; 14(4):256-266.

2. Mannetje L, Ramírez L, Ibrahin M, Sandoval C, Ojeda N, Ku J. Third International Symposium on Silvopastoral Systems. Mérida, Yucatan, México: IUFRO; 2004.

3. Zamora $S$, Ruiz F, Beltrán F, Fenech L, Murillo $B$, Loya J, Troyo E. Régimen hídrico del maíz en una zona áridad, determinando en porcentajes de evaporación. Trop Subtrop Agroecsyt 2011; 13(2):181-186.

4. Marsalis MA, Angadi SV, Contreras, FE. Dry matter yield and nutritive value of corn, forage sorghum, and BMR forage sorghum at different plant populations and nitrogen rates. Field Crops Res 2010; 116(1):52-57.

5. Iptas S, Acar, A.A. Effects of hybrid and row spacing on maize forage yield and quality. Plant Soil Environ 2006; 52(11):515-522.

6. Yilmaz S, Erayman $H$, Gozubenli $H$, Can E. Twin or Narrow Row Planting Patterns versus Conventional Planting in Forage Maize Production in the Eastern Mediterranean. Cereal Res Commun 2008; 36(5):189-199.

7. Sarlangue $T$, Fernado $H$, Calvino $P$, Purcell $L$. Why do maize hybrids responde differently to cariations in plant density. Agron J 2007; 99(4):984-991.

8. Cañadas A, Rade D, Zambrano C, Molina C, Arce L. Evaluación y manejo de fuentes semilleras de Teca en la Estación Experimental Tropical Pichilingue-Ecuador. Avances USFQ 2013; 5(1):64-75.

9. Cañadas L. El mapa bioclimático y ecológico del Ecuador. Quito: Editores Asociados; 1983.

10. SAS Institute INC. 2010. SAS/STATTM. Release 8.0 Ed. Cary. NC. USA.
11. Association of Analytical Communities. Official Methods of the AOAC International. Gaithersbur, MD: AOAC; 2012.

12. Ramírez JO, Montenegro JA, Bravo $\mathrm{SR}$, Hernández MF, Aldaco RA, Ruiz E. Características agronómicas y calidad de maíz forrajero con riego sub-superficial. Téc Pecu Méx 2006; 44(3):351-357.

13. Montenegro A, Lara L, Woo L, Munguía J, Rivera M, Trucíos R. Sistema de irrigación en la comarca de Lagunera de Coahuila y Durando, México. Agrociencia 2012; 46(3):267-278.

14. Baron VS, Najda HG, Stevenson, FC. Influence of population density, row spacing and hybrid of forage corn yield and nutritive value in a cool-season environment. Can J Plant Sci 2006; 86(4):1131-1138.

15. Cabrales R, Montoya R, Rivera J. Evaluación agronómica de 25 genotipos de maíz (Zea maiz) con fines forrajeros en el valle de Sinú Medio. Rev MVZ Córdoba 2007; 12(2):1054-1060.

16. Núñez HG, Faz RC, Gonzáles CF, Peña AR. Madurez de híbridos de maíz a la cosecha para mejorar la producción y calidad del forraje. Téc Pecu Méx 2005; 43(1):69-78.

17. Subedi KD, Smith BL, Smith DL. Response of a leafy and non-leafy maize hybrid to population densities and fertilizer nitrogen levels. Crop Sci 2006; 46(5):1860-1869.

18. Turgut I, Duman A, Bilgili U, Acikgoz E. Alternate Row Spacing and Plant Density Effects on Forage and Dry Matter Yield of Cron Hybrids (Zea maiz L.). J Agron Crop Sci 2005; 191(2):146-151.

19. Buldakli-Çarpici E, Çelik N, Bayran G. Yield and Quality of Forage maize as influenced by Plant Density and Nitrogen Rate. Turk J Fiedl Crops 2010; 15(2):128-132. 
20. Gözübenli H. Influence of Planting Patterns and Plant Density on the Performance of Maize Hybrids in the Eastern Mediterranean Conditions. Inter J Agric Biology 2012; 12(4):556-560.

21. Acosta R. El cultivo del maíz, su origen y clasificación. El maíz de Cuba. Cultivos Tropicales 2009; 30(2):113-120.

22. Sanchez MA, Aguilar CU, Valenzuela N, Sánchez C, Jiménez MC, Villanueva Clemente. Densidad de siembra y crecimiento de maíces forrajeros. Agronomía Mesoamericana. 2011; 22(2):281-295.

23. Gallegos $A$, Martínez $A$, Sánchez M, Figueroa $R$, Berumen $S$, Vengegas J, Quevedo J, Escobedo D, Silos M. Calidad nutricional del maíz forrajero (Zea mays L.) bajo condiciones limitadas de agua de riego. Agrofaz. 2012; 12(1):59-66.
24. Cusicanqui J, Lauer J. Plant Density and Hybrid Influence on Corn Forage Yield and Quality. Agron J. 1999; 91:911-915.

25. Cox WJ, Cherney DJR. Row spacing, plant density and nitrogen effects on corn silage. Agron J. 2001; 93(3):597-602.

26. Peña A, Gonzáles F, Robles F. Manejo agronómico para incrementar el rendimiento de grano y forraje híbridos tardíos de maíz. REMEXCA 2010; 1(1):27-35. 